\title{
THE AFRICA BIBLIOGRAPHY: CHANGE OF EDITOR
}

The current issue of the Africa Bibliography-listing works published in 1990-is the last to be edited by Dr Hector Blackhurst, of the John Rylands University Library of Manchester. It is the seventh volume in the series, a series whose format and production he created. I should like to thank him here on behalf of subscribers, members of the Institute and users of the bibliography who like myself have found it each year an invaluable, reliable work of reference. I wish to thank too the John Rylands University Library and the university authorities at Manchester for their help in the making of Dr Blackhurst's bibliography. We all note also with gratitude the often unacknowledged help of Institute members who over the years have supplied references to works produced in Africa, works which might otherwise never have come to our notice. (I would add that readers of the journal are most welcome to send in such references; all help is much appreciated.)

The bibliography is now in the hands of Christopher Allen, of Edinburgh University-a scholar already well known for previous, more specialised bibliographies as well as for his work on African politics. We are delighted that he has taken on the task of editing the Africa Bibliography and wish him well in a field where everyone recognises how difficult it is to produce an annual volume that is both truly comprehensive and so convenient to use.

Dr Hans Panofsky, Curator Emeritus of Africana at the Melville J. Herskovits Library, Northwestern University, writes: 'Virtually since its beginning in 1926 the International African Institute has published an author and subject bibliography pertaining to Africa. From 1929 to 1970 it appeared in the journal Africa. After that date it appeared as a continuous separate quarterly publication, International African Bibliography. From 1984 the IAI-sponsored bibliography of Africa was edited as an annual volume by Dr Hector Blackhurst. The Institute has indeed been fortunate to have secured the quality and quantity of material contributed by Dr Blackhurst. In the volume for 1984 the listing contained 3,137 subject entries, to which were added eighty-six titles of collective works. By 1991 the subject entries had grown to 6,588 and the collective works to 206 . No doubt the excellence of this great work in the bibliographic realm will be matched by Dr Blackhurst's successor, Christopher Allen, head of Politics at Edinburgh University.' 


\section{Announcing the}

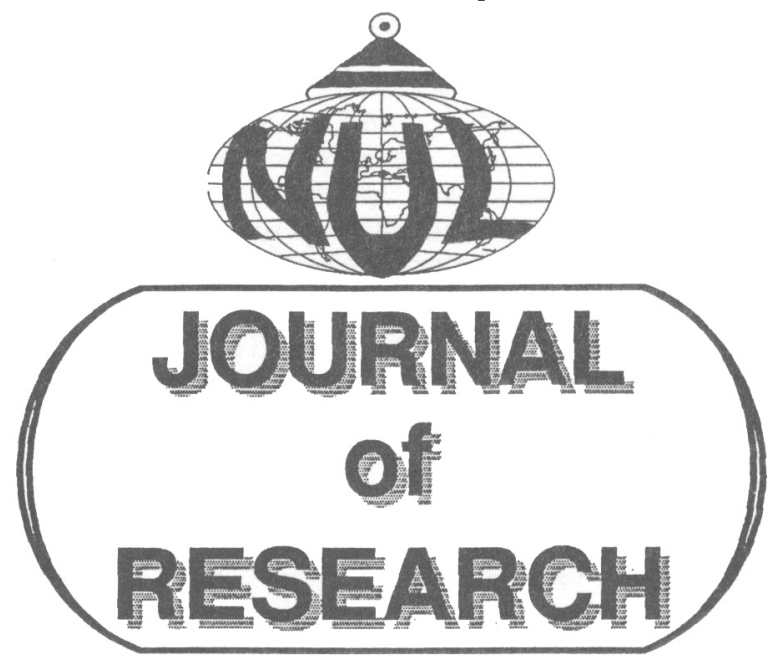

An interdisciplinary journal of research relevant to Lesotho, published by the National University

\section{VOLUME ONE (1991) NOW AVAILABLE}

- Structural adjustment programmes - Education in Swaziland - Sesotho poetry $\cdot$ etc. $\cdot$ Reviews $\cdot$ Reports on work in progress $\cdot$ Annual (cumulative) bibliography

Subscriptions (per annual issue) Lesotho M20.00. Other SADCC and RSA surface mail R22.00/£4.00/\$6.40, air mail R25.00/£.5.00/\$8.00. Other Africa surface mail R25.00/£5.00/\$8.00, air mail R40.00/£8.00/\$13.00. Rest of the world surface mail R30.00/£6.00/\$9.60, air mail R50.00/£10.00/\$16.00.

\section{ALSO NOW AVAILABLE}

NUL Journal of Research Occasional Paper No. 1

\section{A Tentative History of Lesotho Palaeontology by David Ambrose}

Price Lesotho M8.00. Other SADCC and RSA surface mail R10.00/£2.00/ $\$ 3.20$, air mail R12.00/£2.50/\$4.00. Other Africa surface mail R12.00/£2.50/ $\$ 4.00$, air mail R20.00/£4.00/\$6.40. Rest of the world surface mail R15.00/ $£ 3.00 / \$ 4.80$, air mail R25.00/£5.00/\$8.00.

Orders with payment (cheque or money order) to

- The editor

NUL Journal of Research

National University of Lesotho

PO Roma 180

Lesotho 